Article

\title{
In Vitro Comparison of Bioactive Silicon Nitride Laser Claddings on Different Substrates
}

\author{
Elia Marin 1,2 ${ }^{\mathbb{D}}$, Matteo Zanocco 1,3 $\mathbb{D}$, Francesco Boschetto ${ }^{1,2}$, Toshiro Yamamoto ${ }^{2}$, \\ Narisato Kanamura ${ }^{2}$, Wenliang Zhu ${ }^{1}$, Bryan J. McEntire ${ }^{4} \mathbb{D}$, Bhajanjit Sonny Bal ${ }^{4}$, \\ Ryutaro Ashida ${ }^{5}$, Osam Mazda ${ }^{3}$ and Giuseppe Pezzotti 1,3,6,7,*
}

1 Ceramic Physics Laboratory, Kyoto Institute of Technology, Sakyo-ku, Matsugasaki, Kyoto 606-8585, Japan; elia-marin@kit.ac.jp (E.M.); matteo.zanocco@gmail.com (M.Z.); boschetto.cesc@gmail.com (F.B.); wlzhu@kit.ac.jp (W.Z.)

2 Department of Dental Medicine, Graduate School of Medical Science, Kyoto Prefectural University of Medicine, Kamigyo-ku, Kyoto 602-8566, Japan; yamamoto@koto.kpu-m.ac.jp (T.Y.);

kanamura@koto.kpu-m.ac.jp (N.K.)

3 Department of Immunology, Graduate School of Medical Science, Kyoto Prefectural University of Medicine, Kamigyo-ku, 465 Kajii-cho, Kawaramachi dori, Kyoto 602-0841, Japan; mazda@koto.kpu-m.ac.jp

4 SINTX Technologies Corporation, 1885 West 2100 South, Salt Lake City, UT 84119, USA; BMcEntire@sintx.com (B.J.M.); SBal@sintx.com (B.S.B.)

5 Shinsei, Co., Shijohei Kawanishi Rikobo, Kyoto 610-0101, Japan; r.ashida@mold-shinsei.co.jp

6 Department of Orthopedic Surgery, Tokyo Medical University, 6-7-1 Nishi-Shinjuku, Shinjuku-ku, Tokyo 160-0023, Japan

7 The Center for Advanced Medical Engineering and Informatics, Osaka University, Yamadaoka, Suita, Osaka 565-0871, Japan

* Correspondence: pezzotti@kit.ac.jp

Received: 9 November 2020; Accepted: 14 December 2020; Published: 17 December 2020

\begin{abstract}
The performance, durability, and bio-integration of functional biomedical coatings can be enhanced by changing or improving their substrate properties. In this study, we applied silicon nitride powder-based laser claddings to various substrates and undertook an in vitro assessment of their osteoconductive and antibacterial properties. The substrates included common arthroplasty materials: polyethylene, titanium, zirconia-toughened alumina, and zirconia. Multiple analytical techniques were used to characterize the physical and chemical structure of the claddings after deposition. Partial decomposition of the silicon nitride powders occurred during the cladding process, resulting in nitrogen loss during intermetallic formation phases under some substrate and treatment conditions. The osteoconductive capabilities of various laser-cladded substrates were evaluated in a SaOS-2 osteosarcoma cell culture by measuring the amount of bone formation on the coated surface. Antibacterial testing was performed using Gram-positive Staphylococcus epidermidis at 24 and $48 \mathrm{~h}$ of incubation. Silicon nitride coating enhanced both osteoconductive and antibacterial properties.
\end{abstract}

Keywords: laser cladding; antibacterial; osteoconductive; silicon nitride; coating

\section{Introduction}

Over the past 70 years, three generations of biomaterials have been used in total joint arthroplasty (TJA). The first generation was comprised of essentially bioinert compounds, the second generation included bioactive and biodegradable materials, and the third generation is now composed of bioactive substances designed to stimulate specific cellular responses at the molecular level [1]. Yet, despite this evolution, biomaterials are still limited to three classes: metals [2], ceramics [3], and polymers [4]. Each class plays a critical role in the mechanical stability, osteointegration, and wear performance 
of prosthetic joints. Although TJA is considered to be highly effective, with success rates of $>90 \%$ at the 10-year follow-up, aseptic loosening, instability, and infection do occur [5-7]. Wear-induced osteolysis is a significant factor in loosening and instability, but the root cause is a lack of adequate osteointegration. To fight pathogens, practitioners have opted for the sole use of systemic antibiotics to eliminate periprosthetic joint infections, and until recently, little consideration had been given to using implants that inherently exhibit antimicrobial properties. However, currently engineered biomaterials are both osteoconductive and bacteriostatic [8,9]. Several approaches are being taken to provide them with these important characteristics [10-17].

Silicon nitride $\left(\mathrm{Si}_{3} \mathrm{~N}_{4}\right)$, a new third-generation biomaterial, is a bioactive non-oxide ceramic. Its unique surface chemistry is both antibacterial [18-21] and osteoconductive [22-26]. In its monolithic dense form, it is mechanically suitable as an orthopedic structural member and has been approved by multiple regulatory organizations as an implant for spinal arthrodesis [27,28]. Its surface can be highly polished to serve as a prosthetic femoral head, with superior wear performance, or that equivalent to the best currently available alternatives $[29,30]$. As a porous ceramic, it has been shown to have angioand osteo-promotive characteristics [31,32]. It can be added to a polymer to form a composite [33] or applied as a powder coating. In fact, multiple studies have demonstrated that it can impart its beneficial biological characteristics onto other biomaterials [34-39].

Using a laser cladding procedure, we created a sintered $\mathrm{Si}_{3} \mathrm{~N}_{4}$ coating on low-density polyethylene (LDPE), titanium (Ti6A14V), zirconia toughened alumina (ZTA), and yttria-stabilized zirconia (Y-TZP). These coatings were then morphologically and chemically analyzed, and subsequently evaluated for their in vitro osteoconductive and antibacterial characteristics. Mechanical properties and adhesion strength of the silicon nitride coatings were already previously discussed for Ti6Al4V [36] and zirconia [37] substrates.

\section{Materials and Methods}

\subsection{Materials}

SINTX Technologies Corporation, Salt Lake City, UT, USA provided the $\mathrm{Si}_{3} \mathrm{~N}_{4}$ bulk samples and the $\mathrm{Si}_{3} \mathrm{~N}_{4}$ powder used in this investigation. The bulk material, which was used as a positive control in biological testing, was prepared following a procedure previously described in the literature [40]. Silicon nitride powder (which had a trimodal distribution with an average size of $0.8 \pm 1.0 \mu \mathrm{m}$ ) was also obtained from SINTX Technologies Corporation [41].

Low-density polyethylene ( $\mathrm{Mw} \sim 35,000)$ powder was acquired from Sigma Aldrich, Missouri, USA. The material was melted in a vacuum oven at a pressure of $10 \mathrm{~Pa}$ and a temperature of $150^{\circ} \mathrm{C}$ and molded into $30 \times 50 \times 5 \mathrm{~mm}$ plates. The plates were then cut into $10 \times 10 \times 5 \mathrm{~mm}$ samples and polished to a roughness of about $500 \mathrm{~nm}$ Ra.

Annealed medical grade Ti6Al4V ( $\mathrm{Al} 6 \%, \mathrm{~V} 4 \%, \mathrm{C}<0.10 \%, \mathrm{O}<0.20 \%, \mathrm{~N}<0.05 \%, \mathrm{Fe}<0.3 \%$ ) rods with a diameter of $25 \mathrm{~mm}$ were acquired from an industrial manufacturer. The rods were then cut into $5 \mathrm{~mm}$-thick discs and polished to a roughness of about $500 \mathrm{~nm}$ Ra.

Zirconia-toughened alumina (ZTA) samples were obtained by slicing $40 \mathrm{~mm}$ diameter CeramTec Biolox ${ }^{\circledR}$ delta femoral heads to obtain $10 \times 10 \times 5 \mathrm{~mm}$ block. The cutting was performed with a $2 \mathrm{~mm}$ diamond coated blade rotated at $0.5 \mathrm{~mm} / \mathrm{min}$ to reduce monoclinic zirconia transformation during the procedure. The femoral heads, produced in 2016, had a monoclinic zirconia volume fraction of about $6 \%$ before cutting [42].

Yttria-stabilized zirconia (Y-TZP) samples were obtained from fully densified 3Y-TZP bars $(9 \times 4 \times 3 \mathrm{~mm})$ containing $3 \mathrm{~mol} \%$ of yttria $\left(\mathrm{Y}_{2} \mathrm{O}_{3}\right)$ and $0.25 \mathrm{wt} . \%$ alumina $\left(\mathrm{Al}_{2} \mathrm{O}_{3}\right)$. These samples were fabricated from raw powders using a hot isostatic pressing cycle (for $1 \mathrm{~h}$ at $1350{ }^{\circ} \mathrm{C}$ ) following pressure-less sintering (at $1350^{\circ} \mathrm{C}$ ), and possessed an average grain size of about $0.2 \mu \mathrm{m}$ [43]. 


\subsection{Deposition Parameters}

A Vision LWI VERGO-Workstation Nd:YAG laser (wavelength of $1064 \mathrm{~nm}$, max pulse energy: 70 joule, peak power $17 \mathrm{~kW}$, voltage range $160-500 \mathrm{~V}$, pulse time 1-20 ms, spot size 250-2000 $\mu \mathrm{m}$ ) with an automatic $x-y$ stage (lateral resolution: $10 \mu \mathrm{m}$ ) was used to produce a silicon nitride coating. To achieve homogeneous coatings on the various substrate materials, the laser source parameters and the number of layers were adjusted through trial and error before each treatment. The pulse time was optimized to reduce surface overheating (and microstructural changes in titanium) or burning, while the voltage was selected as the lowest value that could grant at least a coverage of about $33 \%$ of the surface on the first cladded layer. The optimized parameters are listed in Table 1.

Table 1. Deposition parameters for various substrates. LDPE, low-density polyethylene; Ti6Al4V, titanium; ZTA, zirconia-toughened alumina; Y-ZTP, yttria-stabilized zirconia.

\begin{tabular}{cccccc}
\hline Substrate & $\begin{array}{c}\text { Voltage } \\
(\mathbf{V})\end{array}$ & $\begin{array}{c}\text { Pulse Time } \\
(\mathbf{m s})\end{array}$ & $\begin{array}{c}\text { Laser Spot Size } \\
(\mathbf{m m})\end{array}$ & Layers & Gas \\
\hline LDPE & 225 & 10 & 2 & 1 & $\mathrm{~N}_{2}$ \\
Ti6Al4V & 425 & 10 & 2 & 3 & $\mathrm{~N}_{2}$ \\
ZTA & 325 & 10 & 2 & 3 & $\mathrm{~N}_{2}$ \\
Y-TZP & 250 & 10 & 2 & 3 & $\mathrm{~N}_{2}$ \\
\hline
\end{tabular}

A layer of silicon nitride powders of about $50 \mu \mathrm{m}$ was placed on the surface of the samples and then heated with a $2 \mathrm{~mm}$ laser spot size under constant $\mathrm{N}_{2}$ gas flow $(1.5 \mathrm{~atm})$. To cover all the surface substrate, the stage moved on the $x-y$ stage with a step of $1 \mathrm{~mm}$, in order to overlap the single laser spots and create a more homogeneous layer.

For the ZTA, the Y-TZP, and the Ti6Al4V, three cladding layers were required to achieve full coverage. Before depositing the next layer, the substrate was rotated by $90^{\circ}$ to form a cross grid. On the other hand, only one layer was applied to the LDPE substrate as laser melts polyethylene. Attempts at a second layer resulted in polymer carbonization.

\subsection{Sample Characterization}

Raman spectra and Raman maps were collected at room temperature using a RAMANtouch instrument (Laser RAMAN Microscope of Nanophoton Corp, Osaka, Japan) with an excitation frequency of $532 \mathrm{~nm}$ green line and equipped with a $400 \times 1340$-pixel charge coupled device (CCD) camera. All data were analyzed using commercially available software (Raman Viewer, Laser RAMAN Microscope of Nanophoton Corp, Osaka, Japan).

Surface morphology was characterized using a confocal scanning laser microscope (Laser Microscope 3D and Profile measurements, Keyence, VKx200 Series, Osaka, Japan) capable of high-resolution optical imaging with depth selectivity. All images were collected at $50 \times$ magnification. The roughness of each sample was measured at 25 random locations.

Scanning electron microscopy (SEM) and energy dispersive X-ray spectroscopy (EDS) (JSM-700 1F, JEOL, Tokyo, Japan) were used to acquire high magnification images and sample chemical composition maps.

\subsection{Biological Testing}

Staphylococcus epidermidis $\left(14990^{\circledR}\right.$ ATCC $\left.{ }^{\mathrm{TM}}\right)$ cells were cultured in heart infusion (HI) broth (Nissui, Tokyo, Japan) at $37^{\circ} \mathrm{C}$ for $18 \mathrm{~h}$ and titrated by colony-forming assay using brain heart infusion (BHI) agar (Nissui). Aliquots of $1 \times 10^{7}$ bacteria were diluted in $10 \mu \mathrm{L}$ of phosphate-buffered saline (PBS) at physiological $\mathrm{pH}$ and ionic strength. The samples underwent preliminary UV sterilization and were distributed into wells. To each well, $1 \mathrm{~mL}$ of bacteria culture was added, and samples were incubated at $37^{\circ} \mathrm{C}$ under aerobic conditions for 12,24 , and $48 \mathrm{~h}$ [23]. 
Cell viability was evaluated using a tetrazolium-based assay from a microbial viability assay kit (WST-8; Dojindo). Substrates with Staphylococcus epidermidis were collected at 24 and $48 \mathrm{~h}$ after cultivation and soaked in $1000 \mu \mathrm{L}$ of PBS in 12-well plates. WST-8 solution was added to each well and Optical Density (OD) values were measured (the absorbance at $490 \mathrm{~nm}$ ) using a plate reader EMax (molecular devices, San Jose, CA, USA) after incubation for 30-60 min.

SaOS-2 human osteosarcoma cells were first cultured and incubated in $4.5 \mathrm{~g} / \mathrm{L}$ glucose DMEM (D-glucose, L-glutamine, phenol red, and sodium pyruvate) supplemented with $10 \%$ fetal bovine serum. They were allowed to proliferate within Petri dishes for about $24 \mathrm{~h}$ at $37^{\circ} \mathrm{C}$. The final SaOS-2 concentration was $5 \times 10^{5} \mathrm{cell} / \mathrm{mL}$. The cultured cells were then deposited on the top surface of samples previously sterilized by exposure to UV-C light for $30 \mathrm{~min}$. In osteoconductivity tests, cell seeding took place in an osteogenic medium which consisted of DMEM supplemented with about $50 \mu \mathrm{g} / \mathrm{mL}$ ascorbic acid, $10 \mathrm{mM} \beta$-glycerol phosphate, $100 \mathrm{mM}$ hydrocortisone, and $\sim 10 \%$ fetal bovine calf serum. The samples were incubated up to 14 days at $37^{\circ} \mathrm{C}$. The medium was changed twice a week during the incubation period. Subsequently, the cells were stained for fluorescence microscopy with green dye to identify osteocalcin (Monoclonal, Clone 5-12H, dilution 1:500, TakaraBio, Kusatsu-shi, Japan) and red dye to show osteopontin (Osteopontin, O-17, Rabbit IgG, 1:500, Immuno-Biological Laboratories (IBL) Inc., Maebashi-Shi, Gunma, Japan) [23].

After exposure to osteoblasts, each batch of samples was observed using fluorescence microscopy (BZ-X700; Keyence, Osaka, Japan). Prior to examination, the sample surfaces were treated with different immunostaining reagents, including Hoechst 33,342 (Dojindo, Kumamoto, Japan), anti-Human Osteocalcin Clone2H9F11F8, and Isotype IgG, Rabbit polyclonal antibody (IBL, Gunma, Japan). Hoechst 33342, a cell nucleus stain (DAPI 4' 6 6-Diamidino-2-phenylindole, dihydrochloride, solution), served to visualize cell proliferation, while the other two antibodies were used to stain mineralization and bone matrix formation concentration quantifying the matrix proteins osteocalcin and osteopontin, respectively. Subsequently, a secondary antibody, Goat anti-Mouse IgG1 Antibody FITC Conjugated (Bethyl Laboratories) was added to enhance signal detection and visualization.

\section{Experimental Results}

\subsection{Surface Comparison}

Surface roughness plays a fundamental role in antibacterial properties and for this reason, the surface morphologies were studied and compared before and after deposition.

Figure 1 shows sample surfaces before and after laser cladding, a treatment which increased the surface roughness of all samples. The roughness of our LDPE plate prepared surface finishing was initially in the range of $\mathrm{Ra}=0.30 \pm 0.02 \mu \mathrm{m}$ (Figure 1a). It increased to Ra $=0.81 \pm 0.28 \mu \mathrm{m}$ after treatment (Figure 1b).

In the case of Ti6Al4V, the initial surface roughness of $\mathrm{Ra}=0.63 \pm 0.09 \mu \mathrm{m}$ (Figure 1c) increased to $\mathrm{Ra}=11.23 \pm 1.11 \mu \mathrm{m}$ (Figure 1d), a value much higher than that measured on either ceramic substrate. This effect was caused by localized melting of the Ti6Al4V substrate, which resulted in an alteration of the coating-substrate interface morphology and the formation of an alpha phase.

In the case of ZTA, the roughness changed from $\mathrm{Ra}=1.02 \pm 0.02 \mu \mathrm{m}$ (Figure 1e) to $\mathrm{Ra}=$ $4.59 \pm 1.29 \mu \mathrm{m}$, due to the presence of partially melted particles. This is clearly visible in Figure 1f.

Because the Y-TZP test bars were polished prior to laser cladding, their initial surface roughness was lower, $\mathrm{Ra}=0.02 \pm 0.01 \mu \mathrm{m}$ (Figure $1 \mathrm{~g}$ ). This increased to $\mathrm{Ra}=1.27 \pm 0.42 \mu \mathrm{m}$ after laser treatment (Figure 1h). 


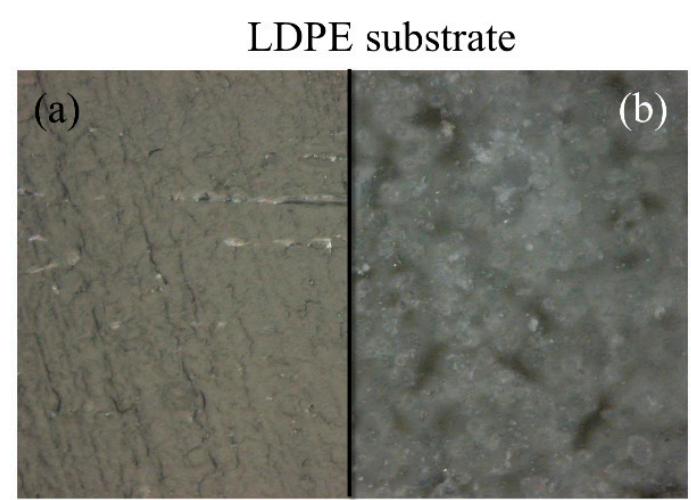

ZTA substrate

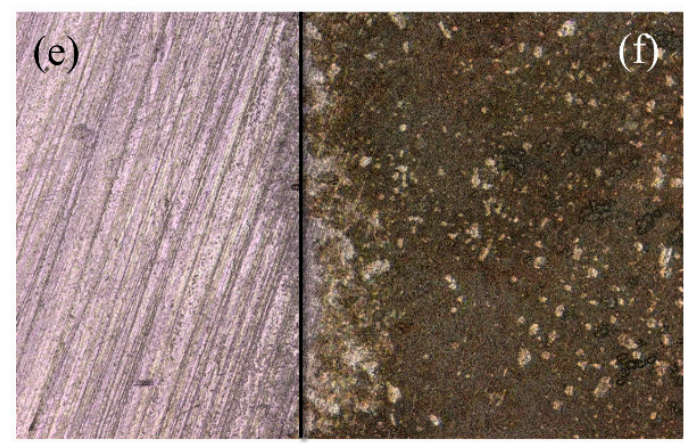

Ti6Al4V substrate

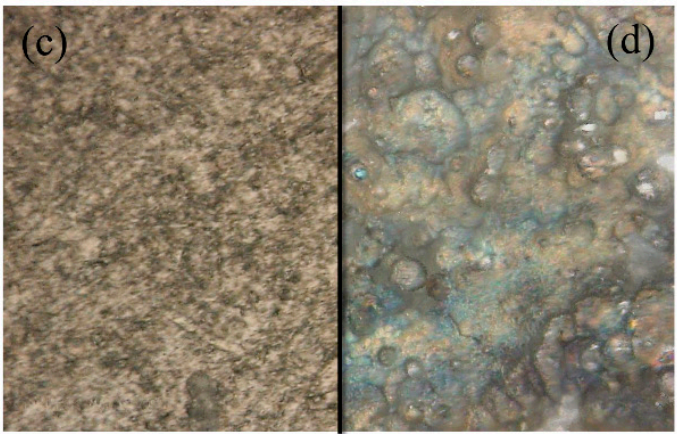

Y-TZP substrate

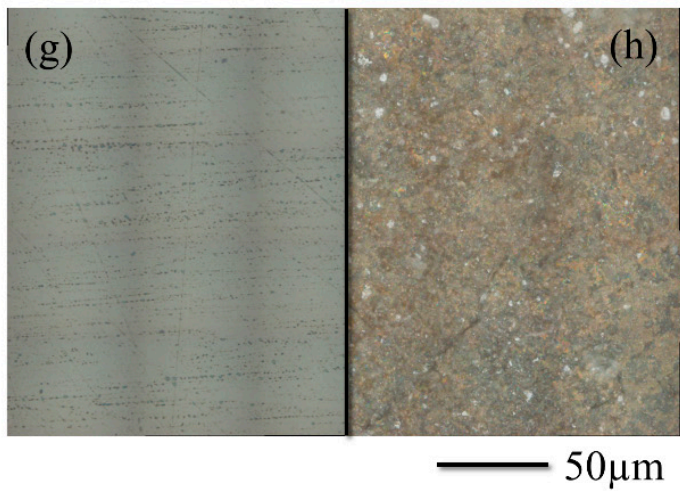

Figure 1. Laser microscope substrate surface images: untreated LDPE (a) and coated LDPE (b), untreated Ti6Al4V (c) and coated Ti6Al4V (d), untreated ZTA (e) and coated ZTA (f), and untreated Y-TZP (g) and coated Y-TZP (h).

On the LDPE substrate, the LDPE matrix under the $\mathrm{Si}_{3} \mathrm{~N}_{4}$ cladding (Figure $2 \mathrm{a}$ ) and on the cross-section images (b), as well as the $\mathrm{Si}_{3} \mathrm{~N}_{4}$ particle penetration inside the LDPE matrix, are visible. Since the silicon nitride particles have a higher absorbance at $1064 \mathrm{~nm}$ [23] when compared to LDPE [44], the ceramic particles heat up and locally melt the polymeric substrate, resulting in the incorporation of silicon nitride into LDPE. As a result, at $225 \mathrm{~V}$ the heated particles melt LDPE (at about $120^{\circ} \mathrm{C}$ ) without causing visible decomposition, which occurs between 350 and $450{ }^{\circ} \mathrm{C}$ [45].

On the Ti6Al4V substrate, the silicon nitride coating is more homogeneous, as can be observed in Figure 2c. The blue signal (titanium) is still present, but mixed with the other elements, it changes to a lavender color. On the cross-section of the Ti6Al4V sample (Figure 2d), it is possible to clearly distinguish between the substrate and the cladded layers. Only occasional formation of Si-Ti intermetallics (see arrow) is evident. Moreover, the coating is clearly composed of two different phases: a silicon-rich (red) layer with a metallic appearance, and a layer with fine dispersion of $\mathrm{Si}_{3} \mathrm{~N}_{4}$ crystals (green) where the nitrogen signal is still intense.

Laser cladding on ceramic substrates resulted in coatings with a similar morphology, composed of partially melted silicon grains (Figure 2e,f). Due to the high melting point and low surface roughness of the ZTA and Y-TZP substrates, the cladded layer did not strongly bond with the substrate, resulting in partial delamination. Previously, we observed an increase in bonding strength when the substrates were pre-scratched using a diamond tip pen [37]. The cross-section image (Figure 2g) of a Y-TZP pre-scratched substrate shows a more homogeneous layer when compared to both the LDPE and the Ti6Al4V substrates. 


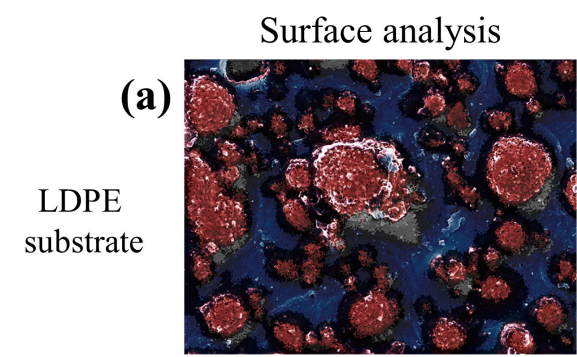

Cross-section analysis
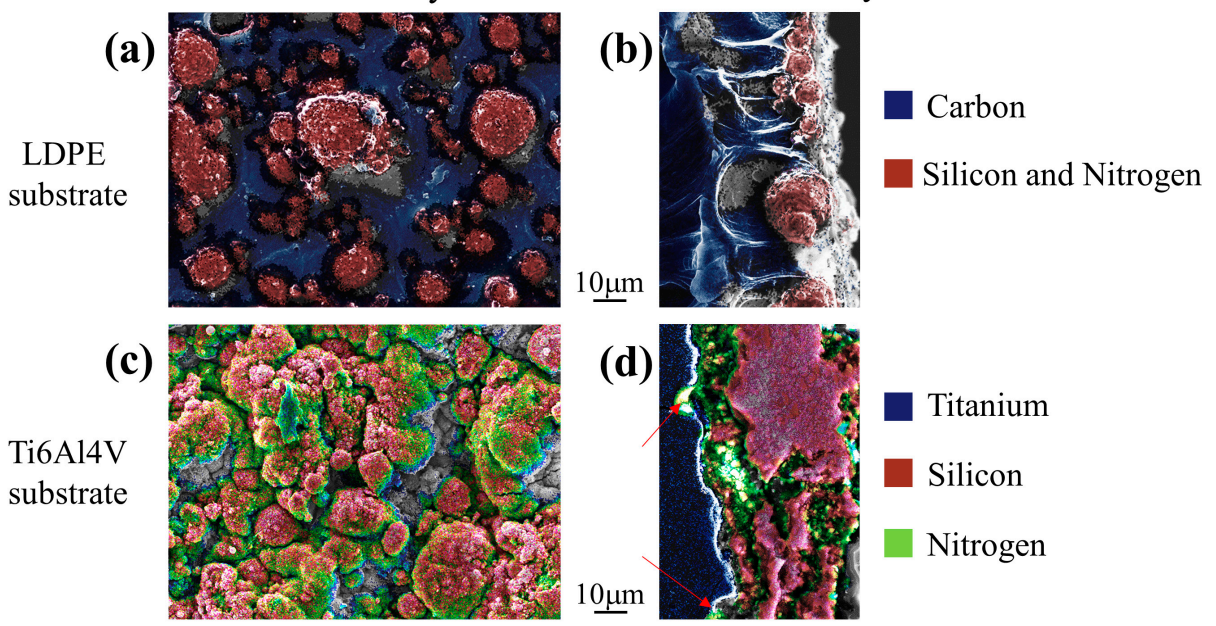

(d)
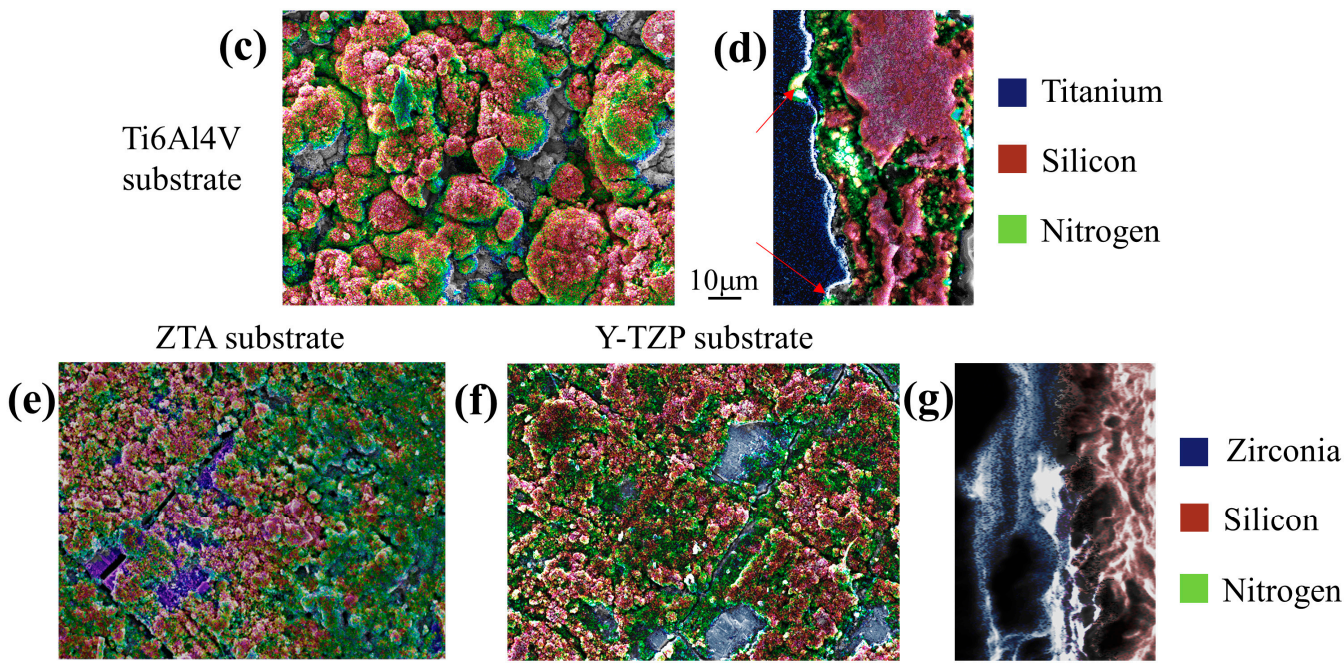

Figure 2. SEM secondary electron images overlapped with EDS compositional maps. LDPE surface analysis (a) and cross-section analysis (b), Ti6Al4V surface analysis (c) and cross-section (d), ZTA surface analysis (e), Y-TZP surface analysis (f), and cross-section analysis (g).

Figures $3-5$ show Raman spectroscopy imaging results for all the substrates used in this experiment.

\section{LDPE substrate}
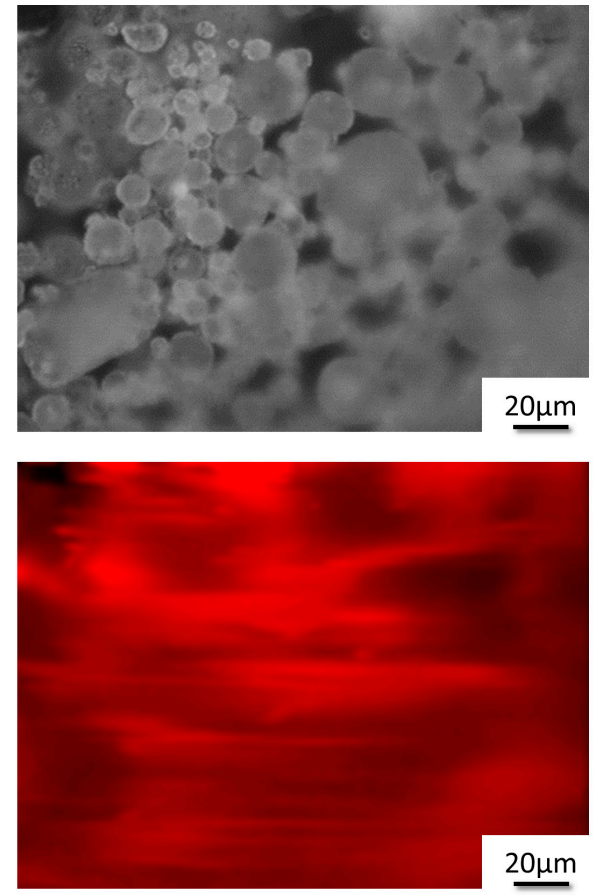

$\mathrm{Si}_{3} \mathrm{~N}_{4}$ phase

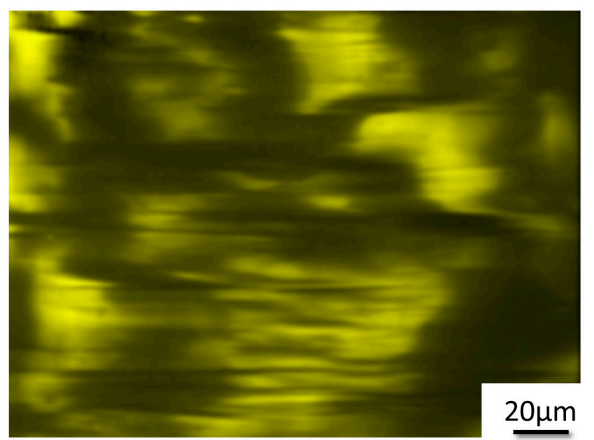

Polyethylene substrate

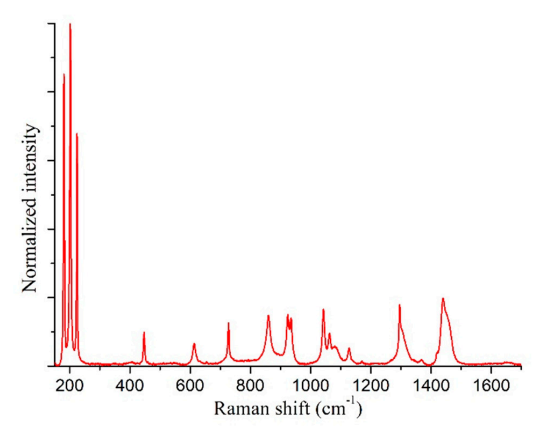

Figure 3. Raman imaging maps and Raman spectra of coated LDPE substrate. 
Ti6Al4V substrate
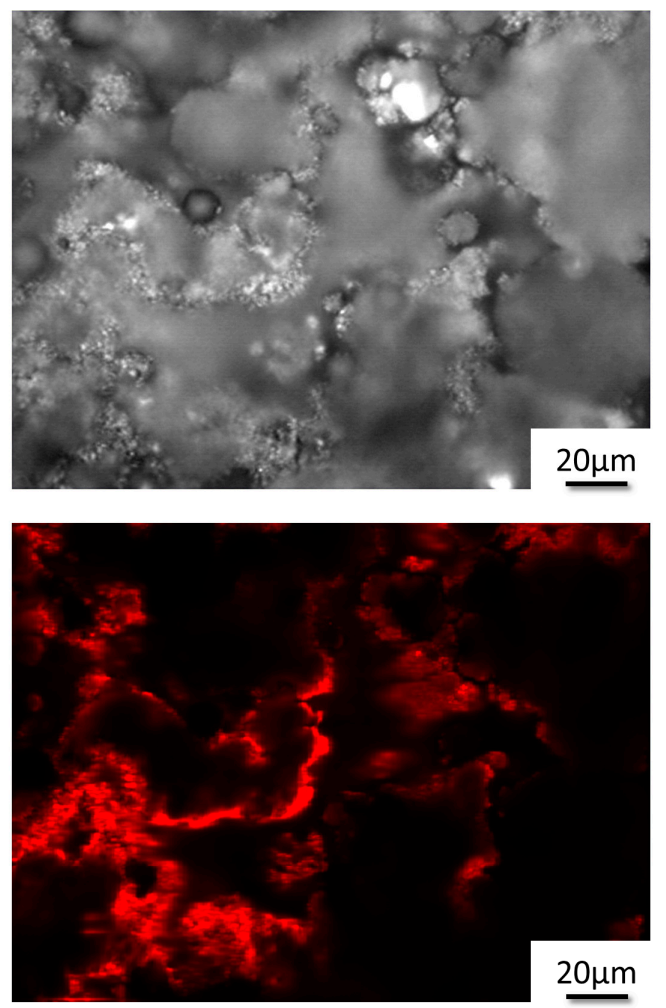

$\mathrm{Si}_{3} \mathrm{~N}_{4}$ phase

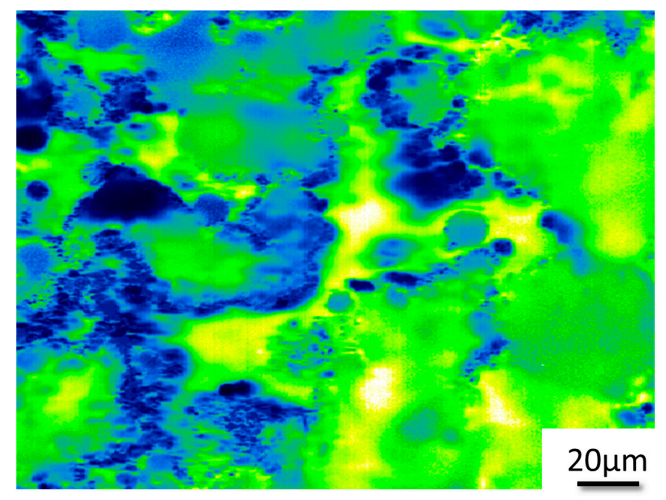

Blue amorphous phase

Green silicon phase

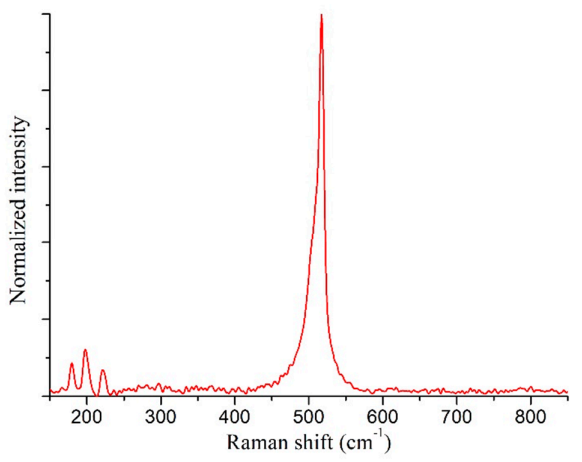

Figure 4. Raman imaging maps and Raman spectra of coated Ti6Al4V substrate.

\section{ZTA substrate}
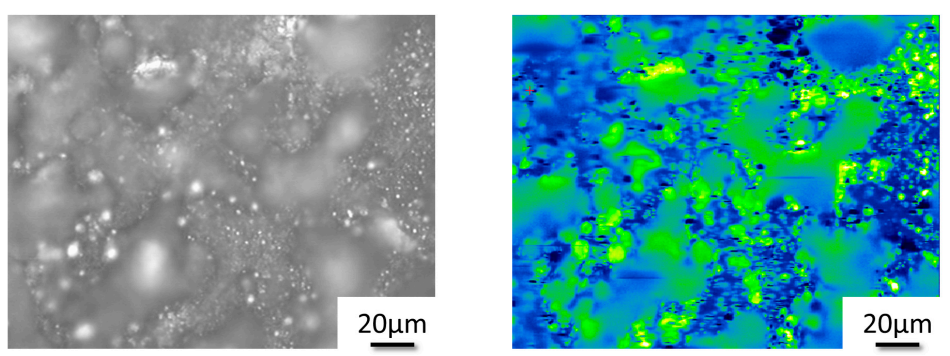

Blue amorphous phase Green silicon phase

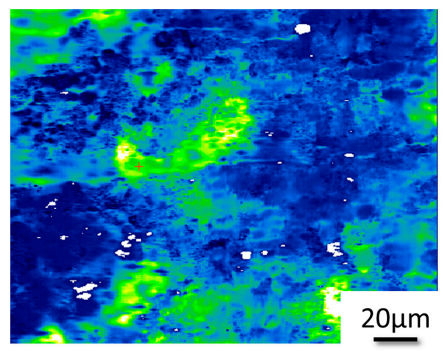

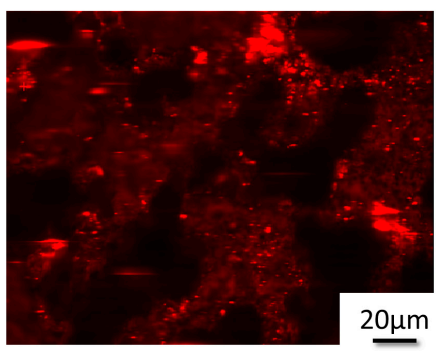

$\mathrm{Si}_{3} \mathrm{~N}_{4}$ phase

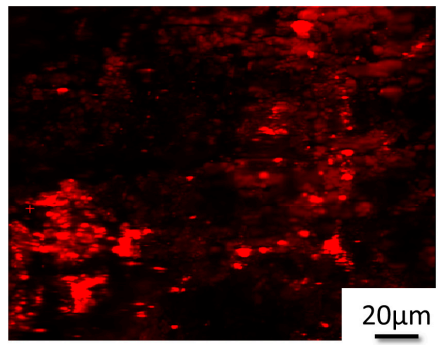

Figure 5. Raman imaging maps of coated ZTA and Y-TZP substrate. 
Figure 3 shows the maps acquired on the LDPE substrate coated with silicon nitride powders. The first image presents the optical morphology of the surface, with clearly visible silicon nitride particles. The color images were obtained from a deconvolution of the Raman signal; the yellow map represents the distribution of the LDPE phase (based on the band at $1300 \mathrm{~cm}^{-1}$ ) and the red map, that of silicon nitride (based on the band at $200 \mathrm{~cm}^{-1}$ ). The Raman spectra confirm the presence of silicon nitride particles at the time when no peaks were observed in the $520 \mathrm{~cm}^{-1}$ region. This was related to the Si-Si bonds and confirmed that the composition of the silicon nitride particles was virtually stoichiometric.

Figure 4 shows the Raman imaging results acquired on the Ti6Al4V substrate. In this case, the silicon nitride powders underwent transformation (degradation) during the laser cladding process. The blue and green image shows the distribution of the amorphous silicon phase (shoulder at about $495 \mathrm{~cm}^{-1}$ ) and the crystalline silicon phase (band at about $520 \mathrm{~cm}^{-1}$ ). The red image shows the regions +in which the silicon nitride phase is still present, as estimated by the presence of triplet peaks at about $200 \mathrm{~cm}^{-1}$. The red areas correspond to optical image regions in which small silicon nitride powder crystals are still clearly visible.

Figure 5 shows the Raman imaging results obtained on the two ceramic substrates. For both materials, the blue/green compositional maps show a strong prevalence of both amorphous and crystalline silicon signals, covering the whole surface. In the case of ZTA, the two phases are equally dispersed, with a slight (about 60\%) amorphous signal prevalence, while for Y-TZP the crystalline phase is mainly localized in a few spots, with a strong $(80 \%)$ amorphous phase prevalence. Both materials showed stoichiometrically-similar residual $\mathrm{Si}_{3} \mathrm{~N}_{4}$ particle dispersion.

Figure 6 shows a qualitative Si-Si bond dependency (as measured by XPS in previous literature reports [37]), with respect to the applied voltage for each material tested. If the applied voltage is under a certain threshold, the coating does not adhere to the substrate and the powder is scattered by the laser beam irradiation. The threshold seems dependent on the physical properties of the materials, such as melting point and absorbance coefficient. Polymer cladding can be achieved at relatively low potentials, due to the melting of the matrix. This results in a virtually stoichiometric coating. In the case of ceramics, the coating requires a higher applied potential to be deposited, but the stoichiometry of the coating changes into a silicon-rich phase. Although metals require high voltage to attach the ceramic coating to the surface, this high power enables the formation of a high content silicon-rich ceramic coating.

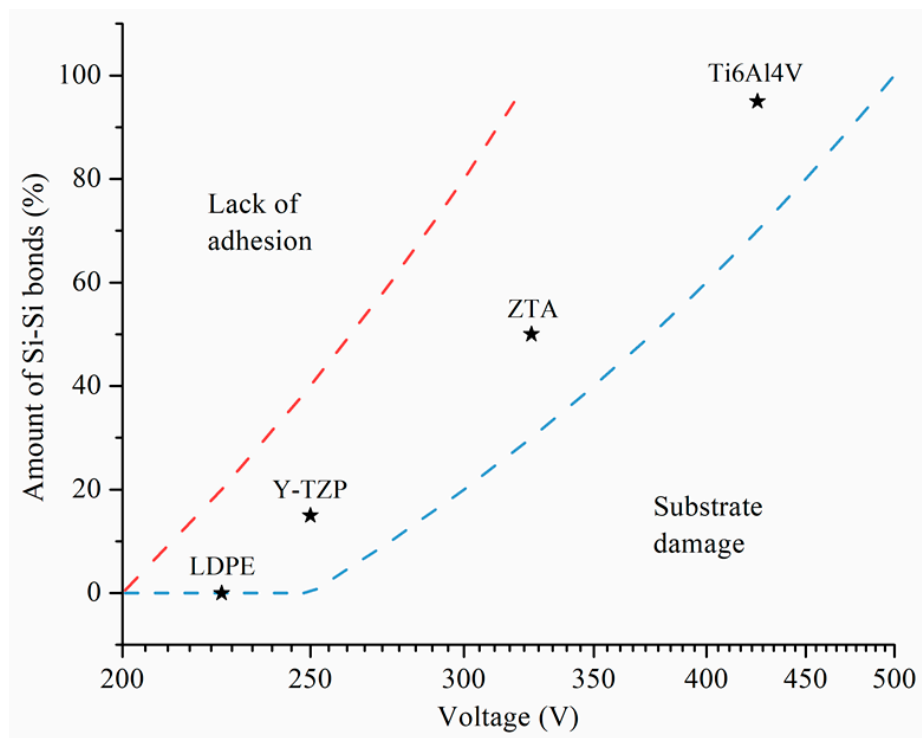

Figure 6. Qualitative representation of the applied voltage/Si-Si bond relationship as measured by $\mathrm{X}$-ray Photoelectron Spectroscopy, as an indicator of substrate chemical composition. 


\subsection{In Vitro Experiment}

Figure 7 shows the microbial viability assays (WST) for three of the four substrates, compared with those of bulk silicon nitride and an untreated reference. As the experiments were conducted at different times and because cell culture conditions (number of cells, viability, etc.) vary in each experiment, there is no way to directly compare results from different materials.
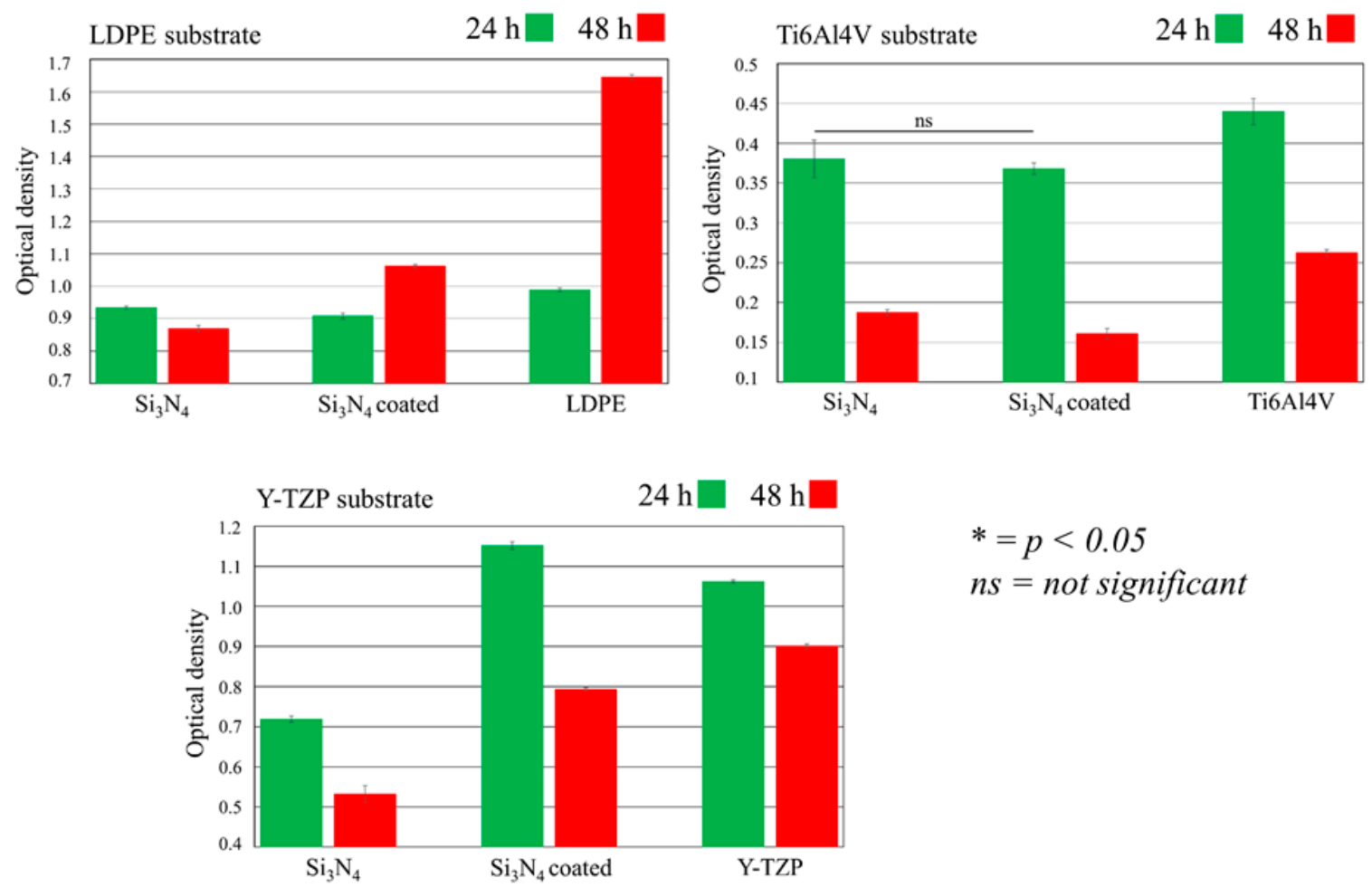

$$
\begin{aligned}
& *=p<0.05 \\
& n s=\text { not significant }
\end{aligned}
$$

Figure 7. Biological assay of Staphylococcus epidermidis as an indicator of bacterial exposure time for all substrates.

It can be observed that $\mathrm{Si}_{3} \mathrm{~N}_{4}$ reference samples usually displayed the lowest optical density at $48 \mathrm{~h}$, with the exception of the Ti6Al4V substrate where the performance is comparable to that of the coated sample. Previous literature reports that the biological effects of silicon nitride are time-dependent and reach their maximum after about $12 \mathrm{~h}$ of treatment [46].

In the case of LDPE substrates, the trend observed for $\mathrm{Si}_{3} \mathrm{~N}_{4}$ is the same, but on polymer and composite substrates, it changed completely. $\mathrm{Si}_{3} \mathrm{~N}_{4}$ bulk is the only class of sample which showed how the bacterial viability decreased over time. The LDPE substrates exhibit a growth of more than $60 \%$ in OD between 24 and $48 \mathrm{~h}$ possessing the highest bacterial amount in both the times. Despite the lowest OD value presenting at $24 \mathrm{~h}$, the $\mathrm{Si}_{3} \mathrm{~N}_{4}$-coated samples showed a slight variation, even if lower than that of the negative control [39].

In the case of $\mathrm{Ti} 6 \mathrm{Al} 4 \mathrm{~V}$, the microbial viability assay at $24 \mathrm{~h}$ showed a higher bacterial count on the Ti6Al4V uncoated sample than on statistically identical uncoated or coated $\mathrm{Si}_{3} \mathrm{~N}_{4}$ samples. At $48 \mathrm{~h}$, a statistically validated decreasing trend of OD was detected on all substrates. However, the $\mathrm{Si}_{3} \mathrm{~N}_{4}$-coated substrate had the lowest $\mathrm{OD}$ value when compared with the two bulk sample classes in which nearly all bacteria underwent lysis [36].

For zirconia samples (ZTA and Y-TZP show similar results), the silicon nitride coated samples treated with S. epidermidis have the highest 24-h living bacteria count, when compared to both references. However, the efficiency increases progressively with time. At $48 \mathrm{~h}$, the optical density of the bacteria is $60 \%$ higher than on silicon nitride, but lower than on Y-TZP monoliths. Similar results have been reported in previous literature [37]. 
Figures 8-10 show the results of the fluorescence microscopy testing with markers for nuclei (blue), osteocalcin (green), and osteopontin (red). The fluorescence microscopy images obtained for various samples show increased bone tissue production for the laser cladded surfaces when compared to the uncoated substrates, as evidenced by both osteocalcin and osteopontin distributions. It must be noted that while both proteins are associated with the presence of bone tissue and their effect is considered synergetic, osteocalcin [47] is mainly observed in mineralized tissue while osteopontin [48] is often associated with bone remodeling.
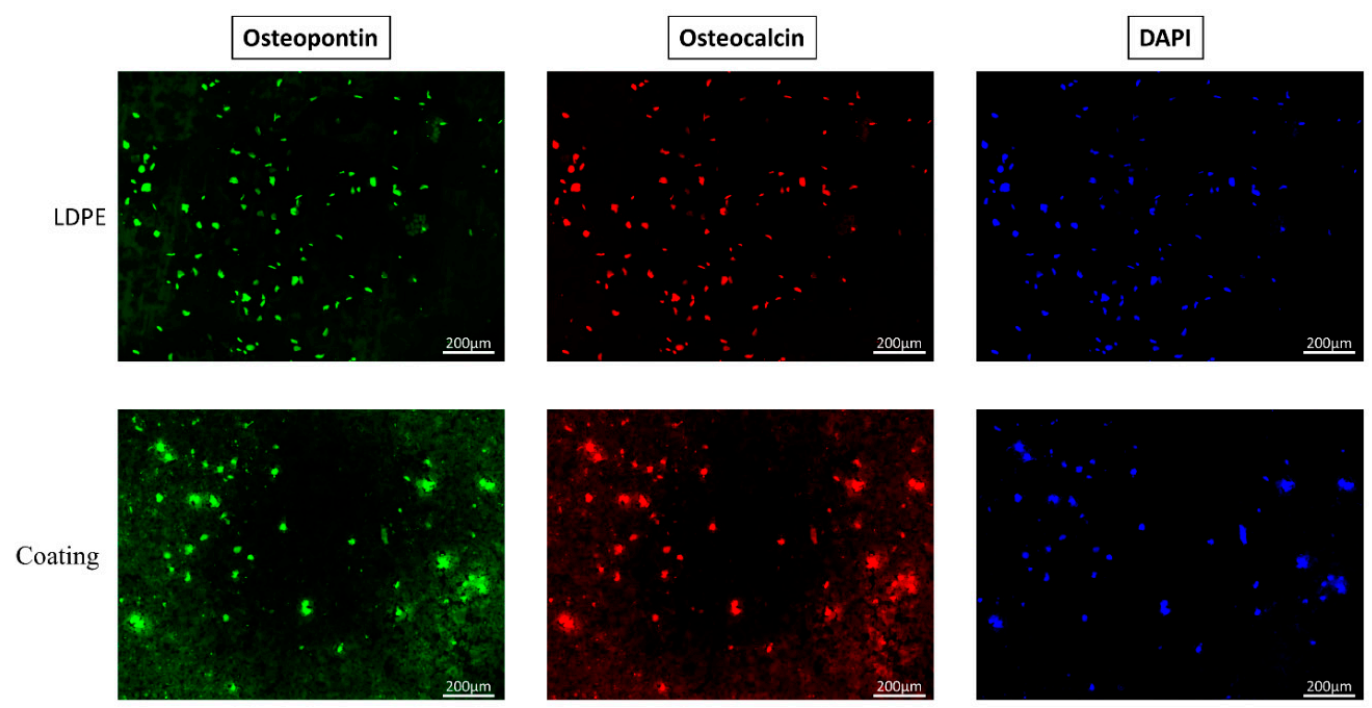

Figure 8. LDPE fluorescence micrograph samples after exposure to SaOS-2 cells. Green and red stains identify osteocalcin and osteopontin, respectively, while blue shows cell nuclei.
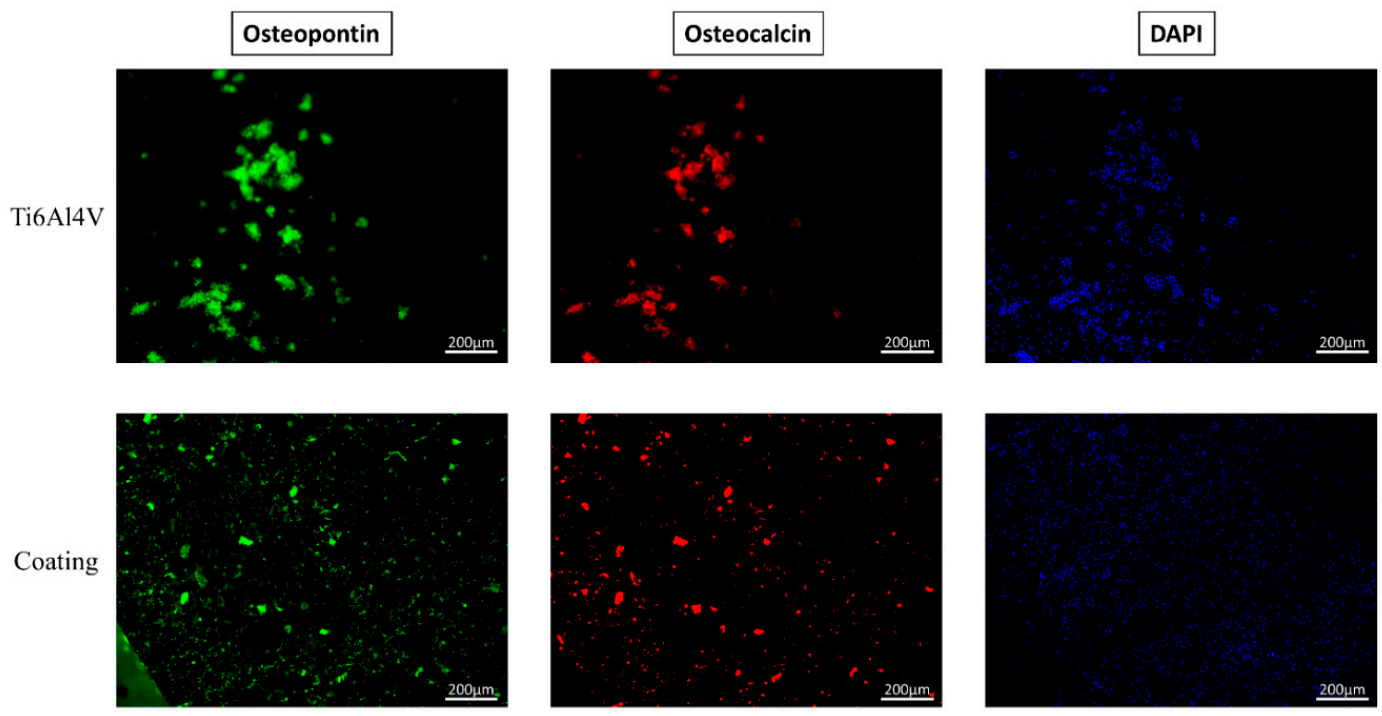

Figure 9. Ti6Al4V fluorescence micrograph samples after exposure to SaOS-2 cells. Green and red stains identify osteocalcin and osteopontin, respectively, while blue shows cell nuclei.

Figure 8 shows the fluorescence microscopy results obtained on the LDPE samples. Unlike zirconia and Ti6Al4V, the uncoated LDPE substrates appear to be colonized by cells and coating application does not significantly affect the amount or distribution of either cell nuclei or bone tissue.

Figure 9 shows the fluorescence microscopy results obtained on the Ti6Al4V alloy substrates. It can be observed that cell nuclei are not homogeneously distributed on the sample surface, forming agglomerates at the center where bone tissue (osteopontin and osteocalcin) is also formed. Coated samples, on the other hand, are more homogeneously covered. 

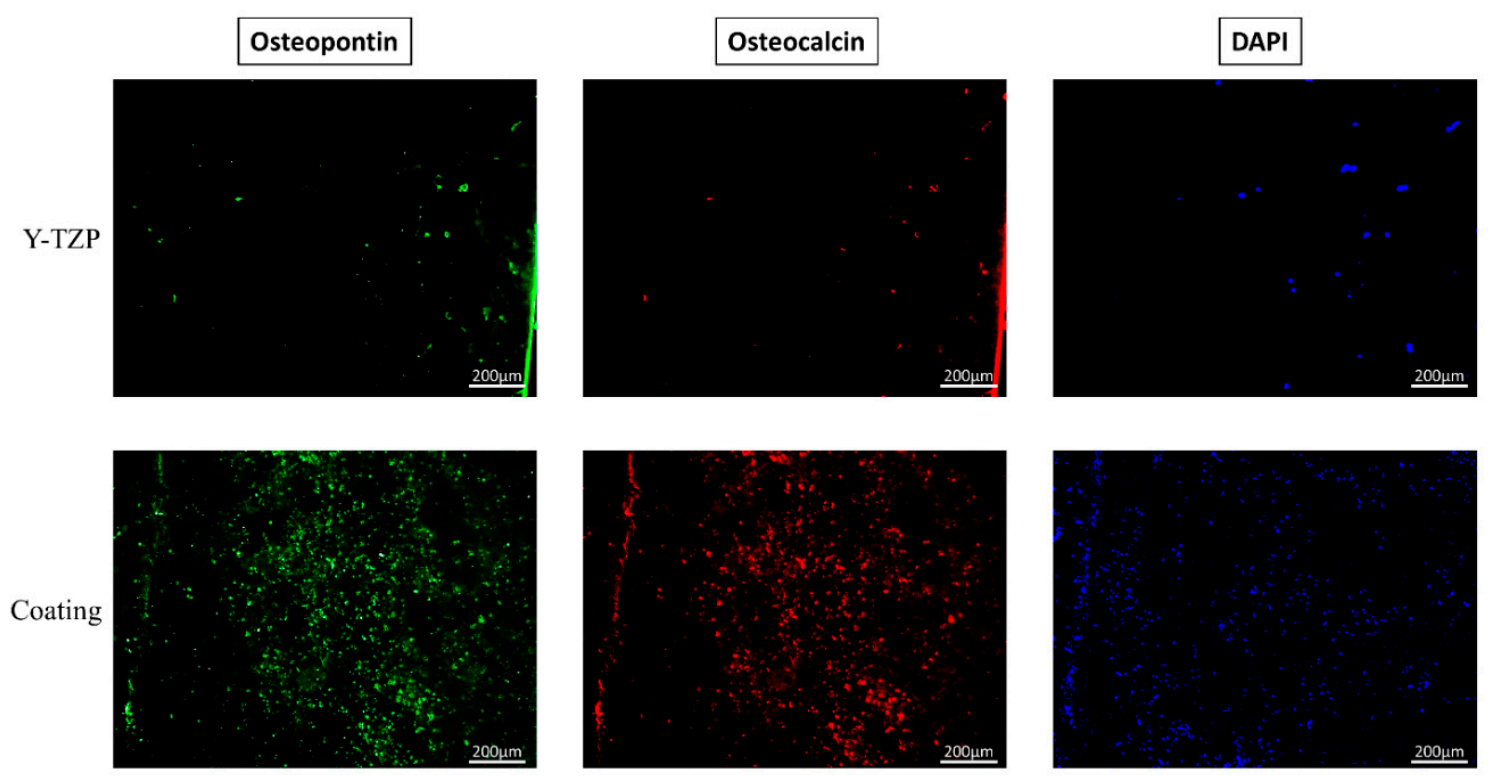

Figure 10. Y-TZP fluorescence micrograph samples after exposure to SaOS-2 cells. Green and red stains identify osteocalcin and osteopontin, respectively, while blue shows cell nuclei.

Figure 10 shows the fluorescence microscopy results obtained on the zirconia substrates (ZTA and Y-TZP show similar results). On the uncoated substrate, it can be observed that the three signals for the non-collagenous bone matrix proteins in osteoblasts: osteocalcin and osteopontin, and for cell nuclei, are barely visible and are only localized in a few spots. Moreover, the increased distribution of blue DAPI signals indicates that more nuclei than bone tissue formed. When the coating is applied, ostepontin and osteocalcin are strengthened and more uniformly distributed over the entire area.

Figure 11 shows the fluorescence analysis of substrate surface bone and cell nuclei quantities before and after treatment.
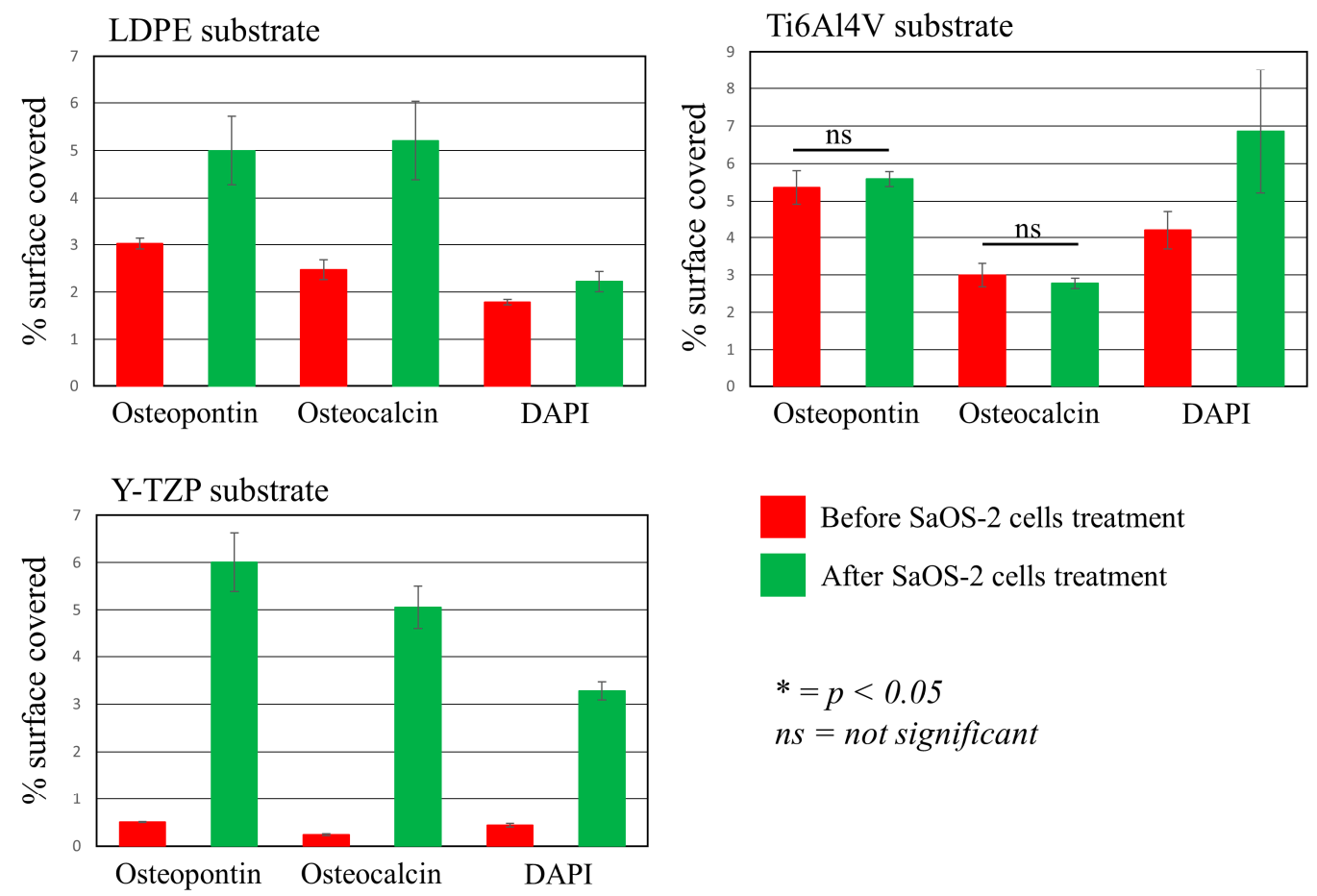

Before SaOS-2 cells treatment

After SaOS- 2 cells treatment

$$
\begin{aligned}
& *=p<0.05 \\
& n s=\text { not significant }
\end{aligned}
$$

Figure 11. Relative surface substrate amounts assigned to the fluorescent probes used for osteocalcin, osteopontin, and cell nuclei based on fluorescence micrograph images. 
For the LDPE substrate, the bone tissue increase is around $2 \%$, but the percentage of cell nuclei still present on the surface is nearly identical to that of the untreated substrate.

For the Ti6Al4V, the number of nuclei is higher than that of the untreated samples, but bone formation is virtually the same for both samples. The only change is a more homogeneous distribution on the substrate surface.

For the Y-TZP substrate, the histogram confirms a high amount of surface bone tissue formation. An increase of $5-6 \%$ of the bone product and $3 \%$ of nuclei on the coated surface is evident.

\section{Discussion}

Laser treatment was seen to convert silicon nitride powder into silicon phase and also into amorphous phase. Previous studies have demonstrated this laser cladding chemical structure as well as new surface properties [36-39]. Laser cladding changes the morphology of the substrates to which it is applied, but the final roughness values seem more dependent on the physical properties of the material and applied voltage than on initial surface roughness. For example, two samples with a similar initial surface roughness, Ti6Al4V and zirconia-toughened alumina (ZTA), showed completely different morphology after treatment. Initial surface roughness did, however, play a clear role in cladded layer adhesion, as can be observed by comparing the ZTA (rough) and pure zirconia (polished) images. Initially, smooth surfaces resulted in partial delamination of the coating [37]. The voltage applied could also be correlated with the composition of the cladded layer: higher values resulted in a lower nitrogen quantity.

Raman spectroscopic images obtained for the different substrates showed the appearance of a strong signal at about $520 \mathrm{~cm}^{-1}$ and related to the presence of Si-Si bonds formed due to the release of nitrogen from the surface. Depending on the position on the spectra, the Si-Si bonds could be associated with the presence of amorphous or nanocrystalline silicon, the second being more abundant at higher voltages.

The antibacterial study was focused on the Gram-positive S. epidermidis mainly because it is one of the first causes of infection in biomedical implants. Moreover, the role of cladded silicon nitride coatings on Gram-negative bacterium test was already presented in previous work [49].

The in vitro bacteria counts summarized in Figure 7 confirm that all silicon nitride-based cladded layers have a time-dependent antibacterial effects. The trend observed in Y-TZP- and Ti6Al4V-coated substrates showed a clear decrease over time. In the LDPE $\mathrm{Si}_{3} \mathrm{~N}_{4}$-coated substrates, the opposite trend was observed, but the increase was less significant compared with that of uncoated LDPE. This is probably due to the presence of $\mathrm{Si}_{3} \mathrm{~N}_{4}$ which, when homogeneously distributed, hindered biofilm formation. The slight increase of OD at $48 \mathrm{~h}$ could be associated with adopted laser treatment because, although particles were fixed without physically modifying the bulk substrates of Ti6Al4V and Y-TZP, the surface was melted by the laser. In LDPE, this resulted in $\mathrm{Si}_{3} \mathrm{~N}_{4}$ particle incorporation. This provided a non-homogeneously $\mathrm{Si}_{3} \mathrm{~N}_{4}$ covered surface, but areas with LDPE were still present as observed in Figure 2.

More bone tissue was formed on substrates with higher fractions of surface silicon phase. In silicon-rich samples, cells produced bone tissue, but at a lower rate than that of other materials.

Substrate roughness also contributed actively to bone formation. The ZTA and Ti6Al4V samples achieved higher surface roughness after laser cladding when compared to other substrates. This influenced the biological response.

\section{Conclusions}

Silicon nitride laser cladding was confirmed to be a feasible technique for the production of bioactive coatings with antibacterial and osteoconductive properties, on a variety of biomaterials used in artificial joints.

The morphology and stoichiometry of the cladded layer were found to be a function of the voltage applied, the amount of which was dependent on the nature and composition of the substrate material. 
The cladded layers contributed to bone formation, as tested with SaOS-2 human osteosarcoma and bacteria and granted a variable degree of protection against Gram-positive bacteria, in particular for Ti6Al4V substrates.

Coatings obtained at higher applied voltages resulted in higher amounts of silicon (nitrogen-deficient). Silicon plays an important role in the bone formation; in fact silicon ions are well known to contribute to the calcification of new bone [50]. For this reason, but also thanks to the increased surface roughness, claddings on titanium resulted in a more homogeneous distribution of cells and bone matrix.

Author Contributions: Conceptualization, E.M. and M.Z.; data curation, M.Z., F.B., and W.Z.; supervision, E.M. and G.P.; visualization, F.B., T.Y., N.K., W.Z., B.J.M., B.S.B., R.A., and O.M.; writing—original draft, M.Z.; writing-review and editing, E.M. and G.P. All authors have read and agreed to the published version of the manuscript.

Funding: We did not receive any grants from funding agencies in the public, commercial, or not-for-profit sectors for this research.

Conflicts of Interest: G.P. was a Scientific Advisor for SINTX Technology Corporation in the early stage of this work.

Data Availability: The raw/processed data required to reproduce these findings will be shared upon request.

\section{References}

1. Navarro, M.; Michiardi, A.; Castaño, O.; Planell, J.A. Biomaterials in orthopaedics. J. R. Soc. Interf. 2008, 5, 1137-1158. [CrossRef]

2. Gibon, E.; Amanatullah, D.F.; Loi, F.; Pajarinen, J.; Nabeshima, A.; Yao, Z.; Hamadouche, M.; Goodman, S.B. The biological response to orthopaedic implants for joint replacement: Part I: Metals. J. Biomed. Mater. Res. Part B 2017, 105, 2162-2173. [CrossRef]

3. McEntire, B.J.; Bal, B.; Rahaman, M.N.; Chevalier, J.; Pezzotti, G. Ceramics and ceramic coatings in orthopaedics. J. Eur. Ceram. Soc. 2015, 35, 4327-4369. [CrossRef]

4. Ramakrishna, S.; Mayer, J.; Wintermantel, E.; Leong, K.W. Biomedical applications of polymer-composite materials: A review. Compos. Sci. Technol. 2001, 61, 1189-1224. [CrossRef]

5. Karachalios, T.; Komnos, G.; Koutalos, A. Total hip arthroplasty: Survival and modes of failure. EFORT Open Rev. 2018, 3, 232-239. [CrossRef]

6. Kenney, C.; Dick, S.; Lea, J.; Liu, J.; Ebraheim, N.A. A systematic review of the causes of failure of Revision Total Hip Arthroplasty. J. Orthop. 2019, 16, 393-395. [CrossRef]

7. Pitta, M.; Esposito, C.I.; Li, Z.; Lee, Y.-Y.; Wright, T.M.; Padgett, D.E. Failure After Modern Total Knee Arthroplasty: A Prospective Study of 18,065 Knees. J. Arthroplast. 2018, 33, 407-414. [CrossRef]

8. Carlson, G.A.; Dragoo, J.L.; Samimi, B.; Bruckner, D.A.; Bernard, G.W.; Hedrick, M.; Benhaim, P. Bacteriostatic properties of biomatrices against common orthopaedic pathogens. Biochem. Biophys. Res. Commun. 2004, 321, 472-478. [CrossRef]

9. Raphel, J.; Holodniy, M.; Goodman, S.B.; Hull, S.M. Multifunctional coatings to simultaneously promote osseointegration and prevent infection of orthopaedic implants. Biomaterials 2016, 84, 301-314. [CrossRef]

10. Thull, R.; Grant, D. Physical and chemical vapor deposition and plasma-assisted techniques for coating titanium. In Titanium in Medicine; Springer: Berlin/Heidelberg, Germany, 2001; pp. 283-341.

11. Serra, J.; González, P.; Chiussi, S.; León, B.; Amor, M.P. Processing of Bioglass Coatings by Excimer Laser Ablation. Key Eng. Mater. 2000, 192, 635-638. [CrossRef]

12. Gallo, J.; Holinka, M.; Moucha, C.S. Antibacterial Surface Treatment for Orthopaedic Implants. Int. J. Mol. Sci. 2014, 15, 13849-13880. [CrossRef]

13. Leach, J.K.; Kaigler, D.; Wang, Z.; Krebsbach, P.H.; Shetye, S. Coating of VEGF-releasing scaffolds with bioactive glass for angiogenesis and bone regeneration. Biomaterials 2006, 27, 3249-3255. [CrossRef]

14. Jun, S.-H.; Lee, E.-J.; Yook, S.-W.; Kim, H.-E.; Kim, H.-W.; Koh, Y.-H. A bioactive coating of a silica xerogel/chitosan hybrid on titanium by a room temperature sol-gel process. Acta Biomater. 2010, 6, 302-307. [CrossRef] 
15. Pobloth, A.-M.; Mersiowsky, M.J.; Kliemt, L.; Schell, H.; Dienelt, A.; Pfitzner, B.M.; Burgkart, R.; Detsch, R.; Wulsten, D.; Boccaccini, A.R.; et al. Bioactive coating of zirconia toughened alumina ceramic implants improves cancellous osseointegration. Sci. Rep. 2019, 9, 16692. [CrossRef]

16. Catauro, M.; Barrino, F.; Bononi, M.; Colombini, E.; Giovanardi, R.; Veronesi, P.; Tranquillo, E. Coating of Titanium Substrates with $\mathrm{ZrO}_{2}$ and $\mathrm{ZrO}_{2}-\mathrm{SiO}_{2}$ Composites by Sol-Gel Synthesis for Biomedical Applications: Structural Characterization, Mechanical and Corrosive Behavior. Coatings 2019, 9, 200. [CrossRef]

17. Catauro, M.; Bollino, F.; Tranquillo, E.; Tuffi, R.; Dell'Era, A.; Ciprioti, S.V. Morphological and thermal characterization of zirconia/hydroxyapatite composites prepared via sol-gel for biomedical applications. Ceram. Int. 2019, 45, 2835-2845. [CrossRef]

18. Bock, R.M.; Jones, E.N.; Ray, D.A.; Bal, B.S.; Pezzotti, G.; McEntire, B.J. Bacteriostatic behavior of surface modulated silicon nitride in comparison to polyetheretherketone and titanium. J. Biomed. Mater. Res. Part A 2017, 105, 1521-1534. [CrossRef]

19. Pezzotti, G. Silicon Nitride: A Bioceramic with a Gift. ACS Appl. Mater. Interfaces 2019, 11, 26619-26636. [CrossRef]

20. Pezzotti, G.; Bock, R.M.; McEntire, B.J.; Jones, E.; Boffelli, M.; Zhu, W.; Baggio, G.; Boschetto, F.; Puppulin, L.; Adachi, T.; et al. Silicon Nitride Bioceramics Induce Chemically Driven Lysis inPorphyromonas gingivalis. Langmuir 2016, 32, 3024-3035. [CrossRef]

21. Akin, S.R.K.; Garcia, C.B.; Webster, T.J. A comparative study of silicon nitride and SiAlON ceramics against E. coli. Ceram. Int. 2021, 47, 1837-1843. [CrossRef]

22. Webster, T.; Patel, A.; Rahaman, M.; Bal, B.S. Anti-infective and osteointegration properties of silicon nitride, poly(ether ether ketone), and titanium implants. Acta Biomater. 2012, 8, 4447-4454. [CrossRef]

23. Pezzotti, G.; McEntire, B.J.; Bock, R.; Boffelli, M.; Zhu, W.; Vitale, E.; Puppulin, L.; Adachi, T.; Yamamoto, T.; Kanamura, N.; et al. Silicon Nitride: A Synthetic Mineral for Vertebrate Biology. Sci. Rep. 2016, 6, 31717. [CrossRef]

24. Pezzotti, G.; Marin, E.; Adachi, T.; Rondinella, A.; Boschetto, F.; Zhu, W.; Sugano, N.; Bock, R.M.; McEntire, B.; Bal, S.B. Bioactive silicon nitride: A new therapeutic material for osteoarthropathy. Sci. Rep. 2017, 7, srep44848. [CrossRef]

25. e Silva, C.G.; König, B., Jr.; Carbonari, M.J.; Yoshimoto, M.; Allegrini, S., Jr.; Bressiani, J.C. Bone growth around silicon nitride implants-An evaluation by scanning electron microscopy. Mater. Charact. 2008, 59, 1339-1341. [CrossRef]

26. Bodišová, K.; Kašiarová, M.; Domanická, M.; Hnatko, M.; Lenčéš, Z.; Nováková, Z.V.; Šajgalík, P. Porous silicon nitride ceramics designed for bone substitute applications. Ceram. Int. 2013, 39, 8355-8362. [CrossRef]

27. Bray, D.; McEntire, B.J. Silicon Nitride-A Ceramic Surgical Implant Material. Bull. Am. Ceram. Soc. 2020, 99, 32-55.

28. Pezzotti, G.; Oba, N.; Zhu, W.; Marin, E.; Rondinella, A.; Boschetto, F.; McEntire, B.; Yamamoto, K.; Bal, B.S. Human osteoblasts grow transitional $\mathrm{Si} / \mathrm{N}$ apatite in quickly osteointegrated $\mathrm{Si}_{3} \mathrm{~N}_{4}$ cervical insert. Acta Biomater. 2017, 64, 411-420. [CrossRef]

29. Bal, B.S.; Khandkar, A.; Lakshminarayanan, R.; Clarke, I.; Hoffman, A.A.; Rahaman, M.N. Fabrication and testing of silicon nitride bearings in total hip arthroplasty: Winner of the 2007 "HAP" PAUL award. J. Arthroplast. 2009, 24, 110-116. [CrossRef]

30. Yorifuji, M.; Affatato, S.; Tateiwa, T.; Takahashi, Y.; Shishido, T.; Marin, E.; Zanocco, M.; Zhu, W.; Pezzotti, G.; Yamamoto, K. Wear Simulation of Ceramic-on-Crosslinked Polyethylene Hip Prostheses: A New Non-Oxide Silicon Nitride versus the Gold Standard Composite Oxide Ceramic Femoral Heads. Materials 2020, $13,2917$. [CrossRef]

31. Anderson, M.C.; Olsen, R. Bone ingrowth into porous silicon nitride. J. Biomed. Mater. Res. Part A 2010, 92, 1598-1605. [CrossRef]

32. Guedes-Silva, C.C.; Rodas, A.C.D.; Silva, A.C.; Ribeiro, C.; Carvalho, F.M.D.S.; Higa, O.Z.; Ferreira, T.D.S. Microstructure, Mechanical Properties and in vitro Biological Behavior of Silicon Nitride Ceramics. Mater. Res. 2018, 21, 21. [CrossRef]

33. Pezzotti, G.; Marin, E.; Adachi, T.; Lerussi, F.; Rondinella, A.; Boschetto, F.; Zhu, W.; Kitajima, T.; Inada, K.; McEntire, B.J.; et al. Incorporating Si3 N4 into PEEK to Produce Antibacterial, Osteocondutive, and Radiolucent Spinal Implants. Macromol. Biosci. 2018, 18, e1800033. [CrossRef] 
34. Bock, R.M.; Marin, E.; Rondinella, A.; Boschetto, F.; Adachi, T.; McEntire, B.J.; Bal, B.S.; Pezzotti, G. Development of a SiYAlON glaze for improved osteoconductivity of implantable medical devices. J. Biomed. Mater. Res. Part B Appl. Biomater. 2018, 106, 1084-1096. [CrossRef]

35. Dai, Y.; Chu, L.; Luo, Z.; Tang, T.; Wu, H.; Wang, F.; Wei, J.; Wei, J.; Wang, X.; Shang, X. Effects of a Coating of Nano Silicon Nitride on Porous Polyetheretherketone on Behaviors of MC3T3-E1 Cells in Vitro and Vascularization and Osteogenesis in Vivo. ACS Biomater. Sci. Eng. 2019, 5, 6425-6435. [CrossRef]

36. Zanocco, M.; Boschetto, F.; Zhu, W.; Marin, E.; McEntire, B.J.; Bal, B.S.; Adachi, T.; Yamamoto, T.; Kanamura, N.; Ohgitani, E.; et al. 3D-additive deposition of an antibacterial and osteogenic silicon nitride coating on orthopaedic titanium substrate. J. Mech. Behav. Biomed. Mater. 2020, 103, 103557. [CrossRef]

37. Marin, E.; Zanocco, M.; Boschetto, F.; Santini, M.; Zhu, W.; Adachi, T.; Ohgitani, E.; McEntire, B.J.; Bal, B.S.; Pezzotti, G. Silicon nitride laser cladding: A feasible technique to improve the biological response of zirconia. Mater. Des. 2020, 191, 108649. [CrossRef]

38. Pezzotti, G.; Marin, E.; Zanocco, M.; Boschetto, F.; Zhu, W.; McEntire, B.J.; Bal, B.S.; Adachi, T.; Yamamoto, T.; Mazda, O. Osteogenic Enhancement of Zirconia-Toughened Alumina with Silicon Nitride and Bioglass@. Ceramics 2019, 2, 554-567. [CrossRef]

39. Zanocco, M.; Marin, E.; Boschetto, F.; Adachi, T.; Yamamoto, T.; Kanamura, N.; Zhu, W.; McEntire, B.J.; Bal, B.S.; Ashida, R.; et al. Surface Functionalization of Polyethylene by Silicon Nitride Laser Cladding. Appl. Sci. 2020, 10, 2612. [CrossRef]

40. McEntire, B.J.; Lakshminarayanan, R.; Thirugnanasambandam, P.; Seitz-Sampson, J.; Bock, R.; O’Brien, D. Processing and characterization of silicon nitride bioceramics. Bioceram. Dev. Appl. 2016, 6, 1. [CrossRef]

41. Lehman, C.W.; Flur, R.; Kehn-Hall, K.; McEntire, B.J.; Bal, B.S.; Bock, R.M. Silicon Nitride Inactivates SARS-CoV-2 in vitro. bioRxiv. 2020. [CrossRef]

42. Affatato, S.; Modena, E.; Toni, A.; Taddei, P. Retrieval analysis of three generations of Biolox@femoral heads: Spectroscopic and SEM characterisation. J. Mech. Behav. Biomed. Mater. 2012, 13, 118-128. [CrossRef]

43. Zhu, W.; Nakashima, S.; Matsuura, M.; Gu, H.; Marin, E.; Pezzotti, G. Raman and X-ray photoelectron spectroscopic characterizations of thermal stability of $3 \mathrm{~mol} \%$ yttria stabilized zirconia ceramics. J. Eur. Ceram. Soc. 2019, 39, 4928-4935. [CrossRef]

44. Boydağ, F.Ş.; Mamedov, S.; Alekperov, V.A.; Özcanli, Y.L. Optical characterization of weakly absorbing PP, PE, and PP/PE films. Opt. Spectrosc. 2003, 95, 225-229. [CrossRef]

45. Tsuchiya, Y.; Sumi, K. Thermal decomposition products of polyethylene. J. Polym. Sci. Part A-1 2003, 6, 415-424. [CrossRef]

46. Marin, E.; Rondinella, A.; Boschetto, F.; Zanocco, M.; McEntire, B.J.; Bal, B.S.; Pezzotti, G. Understanding Silicon Nitride's Biological Properties: From Inert to Bioactive Ceramic. In Key Engineering Materials; Trans Tech Publications Ltd.: Zürich, Switzerland, 2018; Volume 782, pp. 289-296. [CrossRef]

47. Zoch, M.L.; Clemens, T.L.; Riddle, R.C. New insights into the biology of osteocalcin. Bone 2016, 82, 42-49. [CrossRef]

48. Icer, M.A.; Karadağ, M.G. The multiple functions and mechanisms of osteopontin. Clin. Biochem. 2018, 59, 17-24. [CrossRef]

49. Boschetto, F.; Adachi, T.; Horiguchi, S.; Marin, E.; Paccotti, N.; Asai, T.; Zhu, W.; McEntire, B.J.; Yamamoto, T.; Kanamura, N.; et al. In situ molecular vibration insights into the antibacterial behavior of silicon nitride bioceramic versus gram-negative Escherichia coli. Spectrochim. Acta Part A Mol. Biomol. Spectrosc. 2019, 223, 117299. [CrossRef]

50. Carlisle, E.M. Silicon: A Possible Factor in Bone Calcification. Science 1970, 167, 279-280. [CrossRef]

Publisher's Note: MDPI stays neutral with regard to jurisdictional claims in published maps and institutional affiliations. 